\title{
Proinsulin levels in newborn siblings of Type 1 (insulin-dependent) diabetic children and their mothers
}

\author{
F. A. Lindgren ${ }^{1}$, S. G.Hartling ${ }^{2}$, B.E.Persson ${ }^{3}$, M.E. Röder ${ }^{2}$, K.Snellman ${ }^{4}$, C.Binder ${ }^{2}$, G. Dahlquist ${ }^{5}$ \\ 'Department of Pediatrics, Karolinska Institute, Sachs' Children's Hospital, Stockholm, Sweden \\ ${ }^{2}$ Steno Diabetes Center, Gentofte, Denmark \\ ${ }^{3}$ Department of Pediatrics, Karolinska Institute, St. Göran's Children's Hospital, Stockholm, Sweden \\ ${ }^{4}$ Department of Pediatrics, Falu Hospital, Falun, Sweden \\ ${ }^{5}$ Department of Pediatrics, University Hospital, Umeå, Sweden
}

Summary. Elevated proinsulin levels have been observed in healthy first degree relatives of Type 1 (insulin-dependent) diabetic patients. This elevation could reflect a sequele after a previous attack on the beta-cells not necessarily leading to diabetes, or represent a family trait related to the development of diabetes. When cord plasma levels of proinsulin, insulin and C-peptide from 14 newborn siblings of Type 1 diabetic patients were compared with 21 newborn control siblings unrelated to diabetic subjects, no differences were observed. Neither were any differences observed between their mothers at delivery when comparing the same parameters. In cord plasma the proinsulin levels (median and range) were higher than those in plasma from 35 adult fasting women unrelated to diabetic subjects $(10,5-83 \mathrm{pmol} / 1$ vs 4 , 2-33 pmol/1; $p<0.001$ ) whereas the C-peptide levels (median and range) were lower $(0.20,0.11-0.56 \mathrm{nmol} / 1 \mathrm{vs} 0.37$, $0.21-0.69 \mathrm{nmol} / \mathrm{l} ; p<0.001$ ). No differences in insulin levels using a highly specific insulin assay were observed. The results suggest that newborn children have high proinsulin and low C-peptide levels unrelated to heredity of diabetes and that the previously described elevated proinsulin level observed in older first degree relatives of diabetic subjects occurs later in life.

Key words: Type 1 (insulin-dependent) diabetes mellitus, proinsulin, C-peptide, insulin, infant (newborn), siblings.
First degree relatives of patients with Type 1 (insulin-dependent) diabetes mellitus, in particular relatives who are HLA-identical with the diabetic proband or monozygotic twins, have an increased risk of developing Type 1 diabetes $[1,2]$.

Elevated proinsulin levels have been observed in healthy monozygotic twins [3], siblings [4-6], as well as parents and children [6] of Type 1 diabetic patients. The elevated proinsulin level may indicate that the subjects are in a late "prediabetic" phase, a concept supported by the findings of increased proinsulin levels in newly-diagnosed Type 1 diabetic patients $[7,8]$. Another possibility is that the increased proinsulin levels may reflect the sequelae of a previous attack on the beta-cells not necessarily leading to diabetes. Supporting this view is our observation that 89 out of 93 healthy, 10-28-year-old, islet cell antibody (ICA)-negative siblings of Type 1 diabetic patients had fasting proinsulin levels that were above the median value for control subjects who had no diabetes among their first degree relatives [5]. Furthermore, the proinsulin levels were not affected by the HLA-status which the sibling shared with the diabetic proband. Only two of the ICA-negative siblings developed diabetes or impaired glucose tolerance during at least 2.5 years of fol- low-up. A third possibility is that elevated levels of proinsulin represent a family trait related to development of diabetes but not to HLA-status. The latter question could be explored by studies of newborn siblings of Type 1 diabetic patients.

The aim of this study was to compare beta-cell activity assessed by determining proinsulin, insulin and C-peptide in newborn siblings of diabetic patients and their mothers at delivery with control subjects who, among their first degree relatives, had no diabetes. We also compared betacell function in a group of non-pregnant mothers of newlydiagnosed Type 1 diabetic patients with age-matched non-pregnant women without diabetes among their first degree relatives.

\section{Subjects and methods}

\section{Subjects}

This study was approved by the ethics committee of the Karolinska Institute in Stockholm. Informed consent to participate in the study was given.

The study comprised 14 newborn siblings of Type 1 diabetic children and 21 newborn siblings with no diabetes among their first 
Table 1. Characteristics of subjects - mothers of Type 1 diabetic patients and control subjects at delivery and their newborn children., fasting non-pregnant mothers of Type 1 diabetic patients and control subjects

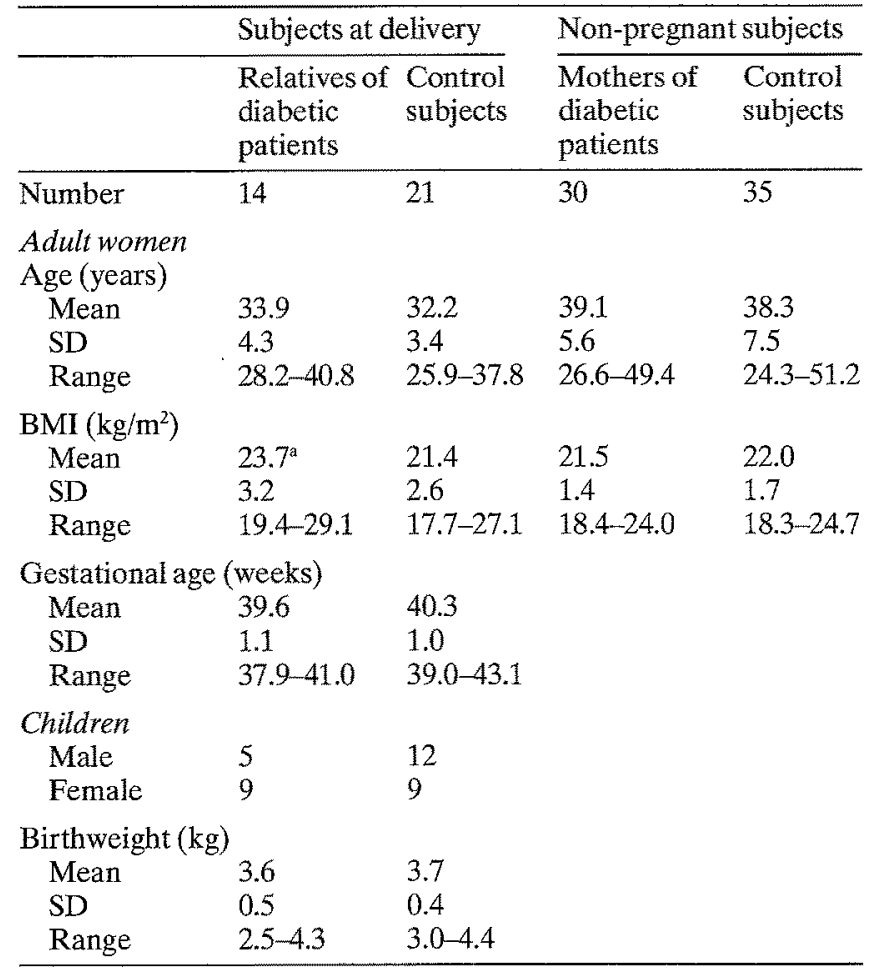

${ }^{a} p=0.02$ vs control subjects at delivery. The body mass index (BMI) values assessed before pregnancy

degree relatives. All their mothers had had normal and uneventful pregnancies, labours and deliveries. None, except one, had had glucosuria during the pregnancy. The mother with glucosuria had a normal glucose tolerance test in gestation week 34 ( $75-\mathrm{g}$ oral glucose load, fasting blood glucose $4.5 \mathrm{mmol} / \mathrm{l}$ and after $120 \mathrm{~min} 7.2 \mathrm{mmol} / \mathrm{l}$ ). All mothers were delivered vaginally. One child in the control group was delivered in breech presentation. For all the newborn children, the Apgar score was more than 8 at $1 \mathrm{~min}$ and 10 at $5 \mathrm{~min}$ after delivery. The characteristics of the mothers and their newborn children are summarized in Table 1.

We also examined 30 healthy, non-obese (body mass index $<25 \mathrm{~kg} / \mathrm{m}^{2}$ ) mothers of children with Type 1 diabetes. Their children had become diabetic at an average age of 9.7 years (range 0.9 16.0 years) and at an average of 2.1 years (range $0.2-4.7$ years) before the study. The control group comprised 35 healthy age-matched women without diabetes among their first degree relatives. None of the subjects studied was taking any medication. The time of bloodsampling in relation to their last menstrual period was not significantly different between the mothers of diabetic children and control women $(16 \pm 9$ vs $12 \pm 9$ days, mean $\pm S D)$. Their age and body mass indices are given in Table 1 .

\section{Methods}

Mixed arterio-venous cord blood, and venous blood from the mother, were taken as close to the delivery as possible and always within $15 \mathrm{~min}$. The venous blood samples from the other groups i.e. mothers of diabetic children and the control subjects were taken the morning after an overnight fast.

The samples were kept on ice until centrifugation. Plasma was frozen at $-20^{\circ} \mathrm{C}$ until analysed. Plasma glucose was measured by a glucose oxidase method with a Beckman Glucose Analyzer 2(Beckman Instruments Inc, Fullerton, Calif., USA). C-peptide was determined by an RIA method using antibody M1230, and second antibody separation $[9,10]$. Insulin was measured by an ELISA method with a detection limit of $10 \mathrm{pmol} / 1$ [11]. Interassay coefficient of variation was $8.6 \%$ at $38 \mathrm{pmol} / \mathrm{l}$. Human C-peptide, proinsulin, split(32$33)$ - and des $(31,32)$-proinsulin did not crossreact in the assay whereas split(65-66)- and des(64,65)-proinsulin crossreacted to $30 \%$ and to $63 \%$ respectively. Proinsulin was measured by an ELISA technique [12]. The detection limit was $1.8 \mathrm{pmol} / \mathrm{l}$ when diluting serum $1: 3$. Interassay coefficient of variation was $9.8 \%$ at $18 \mathrm{pmol} / \mathrm{l}$. Human C-peptide $(10 \mathrm{nmol} / \mathrm{l})$ did not crossreact in the assay. The cross-reactivities of split (32-33)-, des(31,32)-, split(65-66)-, and des $(64,65)$-proinsulin were $60-70 \%, 70-90 \%, 90-100 \%$ and 90 $100 \%$, respectively, from 5 to $80 \mathrm{pmol} / 1$.

\section{Statistical analysis}

Variables that were not normally distributed, C-peptide, insulin, proinsulin and the proinsulin/insulin and proinsulin/C-peptide ratios, were compared using non-parametric statistical methods, i.e. the Mann-Whitney U-test and Spearman's correlation coefficient test. Normally distributed variables were analysed using the Student's $t$-test. A $p$-value less than 0.05 was considered statistically significant. The number of newborn children studied was calculated to be sufficient to detect a difference equal to the variance or more with a power of 0.8 and a $p$-value of 0.05 . As the hypothesis was that proinsulin values might be higher but not lower in relatives of Type 1 diabetic patients compared to control subjects a one-sided test was used, giving a necessary sample size of 13 in each group [13].

\section{Results}

\section{Beta-cell activity in newborn siblings of Type 1 diabetic patients and their mothers at delivery}

Individual values for insulin and proinsulin varied markedly. Glucose, C-peptide, insulin, proinsulin concentrations and the ratio proinsulin/insulin and proinsulin/Cpeptide in cord plasma did not differ between newborn siblings of diabetic patients and control subjects (Table 2). At delivery, the values for glucose, C-peptide, insulin, proinsulin and the ratio of proinsulin/insulin and proinsulin/C-peptide did not differ between mothers of diabetic patients and control subjects (Table 2).

The maternal plasma glucose value correlated with the glucose value in cord plasma $\left(r_{\mathrm{s}}=0.39, p=0.02\right)$. Proinsulin values in maternal plasma and cord plasma correlated $\left(r_{\mathrm{s}}=0.40, p=0.02\right)$, but no significant correlations were observed for C-peptide or insulin.

\section{Beta-cell activity in fasting non-pregnant mothers of Type 1 diabetic patients}

Glucose, C-peptide, insulin, proinsulin concentration and the proinsulin/insulin and proinsulin/C-peptide ratios did not differ between fasting non-pregnant mothers of diabetic patients and control subjects (Table 2). There was no correlation between proinsulin levels and the time that had elapsed since the diabetic proband developed diabetes. 
Table 2. Glucose, C-peptide, insulin and proinsulin values and the proinsulin/insulin and proinsulin/C-peptide ratios of study subjects mothers of Type 1 diabetic patients at delivery, their newborn children, healthy fasting non-pregnant mothers of Type 1 diabetic patients and control subjects

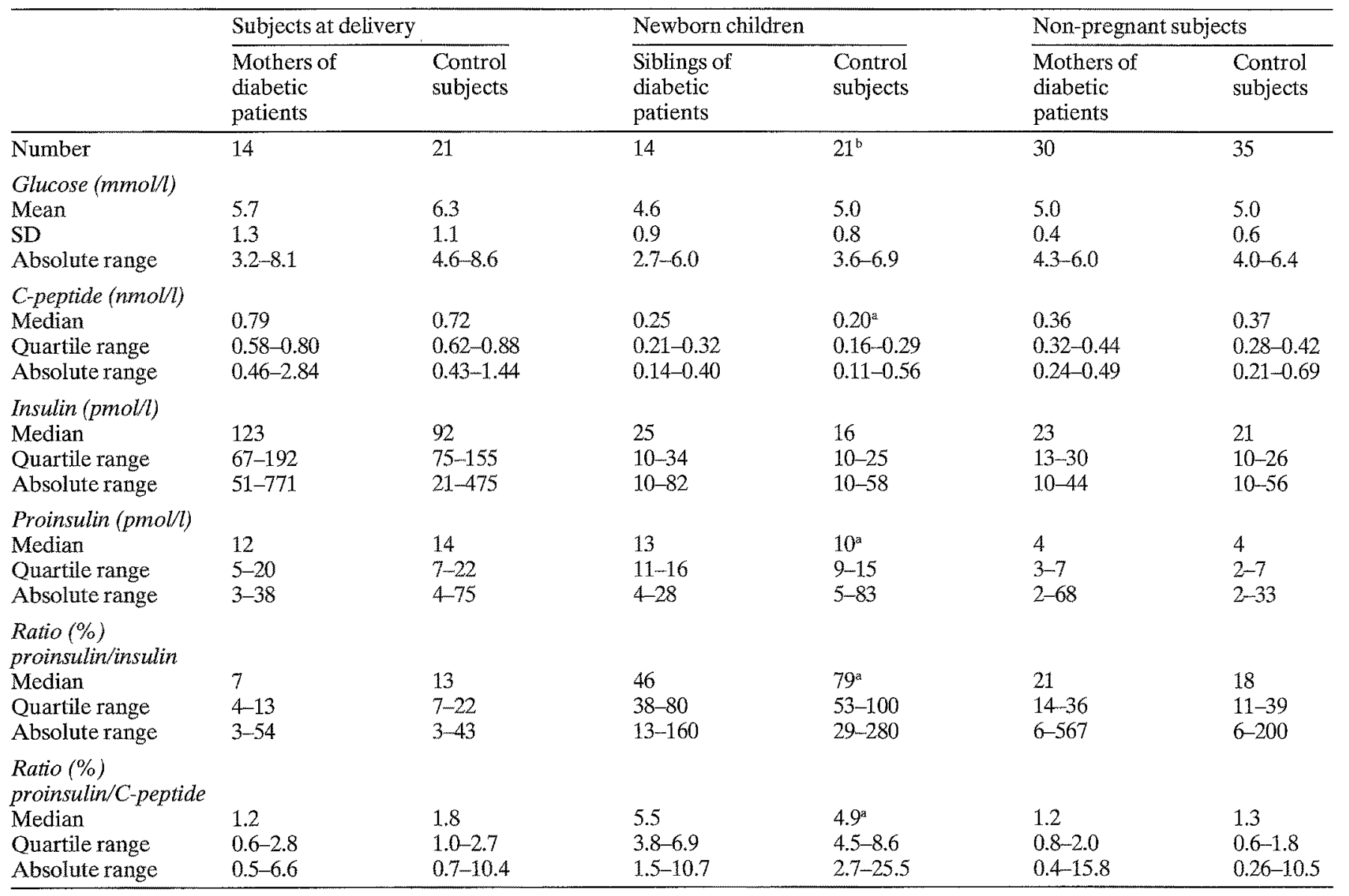

${ }^{a} p<0.001$ vs adult non-pregnant control subjects. ${ }^{b} n=20$ for C-peptide and ratio C-peptide/proinsulin

\section{Beta-cell activity in newborn children compared to adult subjects}

Though the glucose and insulin levels did not differ the Cpeptide values were lower and the proinsulin values higher in newborn children compared to adults (Table 2). The proinsulin/insulin ratio as well as the proinsulin/Cpeptide ratio were higher in cord blood (Table 2). The median molar ratio of C-peptide to insulin was lower in cord plasma $(11.8$, range 5.8-21.3) compared to that of fasting adults $(19.1$, range $6.7-43.0) p=0.003$.

\section{Discussion}

In the present study of newborn siblings of diabetic patients, no differences were found in indicators of beta-cell activity between these siblings and newborn control subjects who had no diabetes among their first degree relatives. Both C-peptide, insulin and proinsulin levels were similar in the groups compared. Thus, the increase in proinsulin concentration previously demonstrated in first degree relatives of diabetic patients [3-6] seems to occur later in life. This change in beta-cell function could reflect beta-cell damage as a result of environmental factors. It could also be a defective maturing/aging process of the beta-cells in the siblings resulting in persistently higher levels of proinsulin later in life. In that case, a different composition of proinsulin immunoreactivity in newborn siblings and control newborns cannot be excluded.

The hypothesis that increased levels of proinsulin in first degree relatives could be a result of beta-cell damage are in accordance with the recent findings of Kahn et al. [14]. They found in a primate model with streptozotocininduced diabetes elevated basal and arginine-induced proinsulin/insulin ratios.

Criticism could be raised that the groups in the present study are small. In our study [5] comparing 93 ICA-negative siblings of diabetic patients and 41 control subjects without diabetes among their first degree relatives the logarithmic values (mean \pm SD) for fasting proinsulin were $0.97 \pm 0.28$ vs $0.62 \pm 0.31(p<0.01)$ i.e. a $50 \%$ difference of the mean value, the difference being similar in magnitude to the standard deviation. In the present study the sample size was sufficient to detect a difference equal to the variance in a one-sided test with a power of 0.8 and a $p$-value of 0.05 . Of course differences of smaller magnitude might not have been disclosed.

Mothers of newly-diagnosed Type 1 diabetic children did not differ in proinsulin values when compared to 
women without diabetic relatives. Not even at delivery was a difference in proinsulin levels between the two groups of mothers observed. The glucose, C-peptide, insulin and proinsulin concentrations were, as expected, higher at delivery than those seen in fasting adults, a result of labour and increased insulin resistance during pregnancy [15]. In contrast to the present observation, in another study, elevated fasting proinsulin levels were reported in parents to Type 1 diabetic patients [6]. The reason for the discrepancy is unclear but may be attributed to differences in the study populations. Our patients were younger, had lower body mass indexes and included only females.

In cord plasma, the proinsulin levels were higher and the C-peptide levels lower compared to the levels in fasting adult subjects. Consequently the ratios of proinsulin/insulin and proinsulin/C-peptide were higher in newborn infants compared to adults. This observation was consistent with previous reports of increased proinsulin and decreased C-peptide levels in healthy infants $[16,17]$.

The molar ratio between C-peptide and insulin was lower in newborn infants than in adults. This low ratio has been described earlier but in these reports proinsulin and conversion intermediates have crossreacted in the insulin assay giving biased ratios $[17,18]$. In the present insulin assay where proinsulin and most conversion intermediates did not crossreact, the lower C-peptide/insulin ratio might indicate a different metabolic clearance rate for insulin and/or C-peptide in newborns compared with adults. A diminished hepatic extraction of insulin in this age group has been suggested to explain this observation [17]. It may be noted, however, that the comparison is made between a non-steady-state (cord plasma) and a steady-state condition (fasting adult plasma).

In conclusion, beta-cell activity in newborn siblings of Type 1 diabetic patients does not differ from that of healthy newborn infants without diabetes among their first degree relatives. Thus, the raised proinsulin level earlier described in healthy siblings of Type 1 diabetic patients seems to occur later in life and may be caused by environmental factors.

Acknowledgements. This study was supported in part by grants from the Karolinska Institute, the Swedish Society of Medicine, "Förenade Liv" Mutual Group Life Insurance Company, the Samariten Foundation and the "Mjölkdroppen" Association. We highly appreciate the assistance of Ms. S. Kjellberg and Ms. J.Falk Brönnum for peptide analyses and Ms. S. Mikkelsen for the preparation of the manuscript.

\section{References}

1. Gorsuch AN, Spencer KM, Lister J, Wolf E, Bottazzo GF, Cudworth AG (1982) Can future type 1 diabetes be predicted? A study in families of affected children. Diabetes 31:862-866
2. Olmos P, A'Hern R, Heaton DA et al. (1988) The significance of the concordance rate for type 1 (insulin-dependent) diabetes in identical twins. Diabetologia 31:747-750

3. Heaton DA, Millward BA, Gray IP et al. (1988) Increased proinsulin levels as an early indicator of B-cell dysfunction in nondiabetic twins of type 1 (insulin-dependent) diabetic patients. Diabetologia 31: 182-184

4. Hartling SG, Lindgren F, Dahlquist G, Persson B, Binder C (1989) Elevated proinsulin in siblings of IDDM patients independent of HLA identity. Diabetes 38: 1271-1274

5. Lindgren FA, Hartling SG, Dahlquist GG, Binder C, Efendic S, Persson BE (1991) Glucose-induced insulin response is reduced and proinsulin response increased in healthy siblings of type 1 diabetic patients. Diabetic Med 8: 638-643

6. Spinas GA, Snorgaard O, Hartling SG, Oberholzer M, Berger W (1992) Elevated proinsulin levels related to islet cell antibodies in first-degree relatives of IDDM patients. Diabetes Care 15: 632637

7. Heding LG, Ludvigsson J, Kasperska-Czyzykowa T (1981) Bcell secretion in non-diabetics and insulin-dependent diabetes. Acta Med Scand [Suppl] 656: 5-9

8. Snorgaard O, Hartling SG, Binder C (1990) Proinsulin and Cpeptide at onset and during 12 months cyclosporin treatment of type 1 (insulin-dependent) diabetes mellitus. Diabetologia 33: $36-42$

9. Heding LG (1975) Radioimmunological determination of human C-peptide in serum. Diabetologia 11: 541-548

10. Faber OK, Markussen J, Naithani VK, Binder C (1976) Production of antisera to synthetic benzyloxycarbonyl-C-peptide of human proinsulin. Hoppe-Seyler's Z Physiol Chem 357: 751-757

11. Andersen L, Dinesen B, Jörgensen PN, Poulsen F, Röder ME (1993) Enzyme immunoassay for intact human insulin in serum or plasma. Clin Chem (in press)

12. Hartling SG, Dinesen B, Kappelgård A-M, Faber OK, Binder C (1986) ELISA for human proinsulin. Clin Chim Acta 156: 289 297

13. Snedecor G, Cochran W (1980) Statistical methods. 7th edn. Iowa State University Press, pp 104-105

14. Kahn SE, McCulloch DK, Schwartz MW, Palmer JP, Porte D Jr (1992) Effect of insulin resistance and hyperglycemia on proinsulin release in a primate model of diabetes mellitus. J Clin Endocrinol Metab 74: 192-197

15. Cousins L (1991) Insulin sensitivity in pregnancy. Diabetes 40 [SuppI 2]: 39-42

16. Heding LG, Persson B, Stangenberg M (1980) B-cell function in newborn infants of diabetic mothers. Diabetologia 19: 427.432

17. Knip M, Åkerblom HK (1981) Plasma C-peptide and insulin in neonates, infants and children. J Pediatr 99: 103-105

18. Knip M, Lautala P, Leppäluoto J, Åkerblom HK, Kouvalainen K (1983) Relation of enteroinsular hormones at birth to macrosomia and neonatal hypoglycemia in infants of diabetic mothers. J Pediatr 103: 603-611

Received: 30 November 1992

and in revised form: 22 February 1993

Dr. F. Lindgren

Sachs' Children's Hospital

Box 17912

S-118 95 Stockholm

Sweden 